\title{
THE IMPLICATIONS OF FINANCIAL CONSTRAINTS: AN EXPLORATORY STUDY AMONG LODGING FIRMS IN U.S.A
}

\author{
Michalis TOANOGLOU* \\ Woosong University, SIHOM Department, 171 Dongdaejeon-ro, \\ Dong-gu 34606 Daejeon, South Korea, e-mail: mtoanoglou@sis.ac.kr
}

\begin{abstract}
Citation: Toanoglou, M. (2018). THE IMPLICATIONS OF FINANCIAL CONSTRAINTS: AN EXPLORATORY STUDY AMONG LODGING FIRMS IN USA. GeoJournal of Tourism and Geosites, 23(3), 675-683. https://doi.org/10.30892/gtg.23305-319
\end{abstract}

\begin{abstract}
The purpose of this exploratory study is to analyze the nature and implications of financial constraint problems in the American lodging sector. For this purpose, the lodging firms' financial performance measures, such as EBITDA, sales, sales growth, return on assets, and profit margin are examined to compare the extent to which financing, investment, dividend, and cash holding policies diverge between financially constrained and unconstrained lodging firms. The results show that financially constrained firms are smaller in size and value, have lower cash, make less investments, pay lower dividends, generate lower revenues, some of which contradict the findings in mainstream corporate finance literature, where higher cash holdings and better performance were reported for financially constrained firms. Although these firms have negative return on assets and profit margin, they have higher financial leverage and promising growth opportunities. Managerial implications are discussed within the realm of financing, dividend, investment, and cash management policies.
\end{abstract}

Keywords: financial constraints, lodging, firm performance, investment, financing, finance

\section{INTRODUCTION}

The implications of financial constraints on firms' investment, financing, dividend, and cash holding polices have been extensively examined in mainstream corporate finance literature. The debate over whether and the extent to which financial constraints affect firms' abovementioned policies have started with the so-called irrelevance theorem proposed by Modigliani and Miller (1958). In their seminal paper, the authors argued that positive net present value (NPV) projects create value for the firm regardless of whether firm uses internal or external capital to finance their projects. That is, financing decision of investments does not affect the profitability of investments and hence the source of capital is irrelevant to investment decisions. Nevertheless, empirical studies have provided substantive evidence against the irrelevance theorem showing that essentially

\footnotetext{
* Corresponding author
} 
financing and investment decisions are dependent (Myers \& Majluf, 1984; Fazzari et al., 1988; Franzoni, 2009; Khatami et al., 2014). The main argument is that asymmetric information problem exists in the capital markets, which may create a significant variation between the cost of internal and external funds for financially constrained firms (Whited \& Wu, 2006). The purpose of this study is to analyze the nature and implications of financial constraints problem in the American lodging sector. For this purpose, the lodging firms' performance measures are examined to compare the extent to which financing, investment, dividend, and cash holding policies diverge between financially constrained and unconstrained lodging firms.

\section{LITERATURE REVIEW}

Firms are considered financially constrained "if they face a wedge between the internal and external costs of funds. A firm is considered more financially constrained as the wedge between its internal and external cost of funds increases" (Kaplan \& Zingales, 1997, 172). The margin between the cost of internal and external funds might be so high that it could turn a positive NPV investment into negative. Consequently, the degree of financial constraints affects corporations' investment, financing, dividend, and cash holding policies. Studies of Fazzari et al. (1988), Kaplan and Zingales (1997), and Whited and $\mathrm{Wu}$ (2006), to mention a few, showed that financially constrained firms' investments are very sensitive to internal funds whereas unconstrained firms' investments are not related to internal funds. In the same vein, Franzoni (2009), Denis and Sibilkov (2009), and more recently Khatami et al. (2014) showed that cash is more valuable in financially constrained firms because these firms have greater investment opportunities.

They argue that financially constrained firms will be able to fund their valueincreasing investments with retained cash and hence shareholders of financially constrained firms place higher value in cash. Although the implications of financial constraints have been widely studied in mainstream corporate finance literature, these studies do not consider the unique features of the lodging industry. Lodging firms experience challenges to sustain their profits due to economically sensitive nature of this business. Hotel room prices and occupancy rates fluctuates throughout a typical year and fall significantly during economic downturns. Financially constrained lodging firms might experience difficulties financing their projects, which primarily consist of real estate properties that require substantial initial and ongoing capital investments. The following quote from a property report on Wall Street Journal summarizes the nature and risk of investments in the lodging industry (Karmin, 2016).

"Shares of U.S. hotel operators, owners and timeshare companies tumbled more than 22\% in 2015 compared with flat returns for the broader U.S. stock market, and are down another 13\% year to date, according to Goldman Sachs Group Inc., nearly twice the broad market's drop. The recent financial market volatility has caused activity for lodging deals in the commercial mortgage-backed securities market-the main source of debt financing for big hotel transactions-to slow to a trickle."

This information collectively establishes the needs for assessment of the implications of financial constraints in the lodging firms' financing, investment, dividend, and cash holding policies. Canina et al. (2001) and more recently Kim \& Gu (2009) investigated lodging firms' dividend paying policies. The results from these studies showed that lodging firms gain positive returns from dividend payments and that large firm with fewer investment opportunities pays more dividends. Sheel (1994) analyzed the debt behavior of lodging firms and found that the lodging industry has unique short- and long-term debt behavior determining their leverage ratios. Dalbor et al. (2007) examined the relationship between long-term debt behavior and lodging firms' value and concluded 
that long-term debt positively affects firm value as opposed to previous findings in corporate finance literature. Kim \& Jang (2012) compared the financial constraint levels of Hotel Real Estate Investment Trusts (REITs) and C-corporation hotels based on Tobin's Q and showed that Hotel-REITs are more constrained than C-corporation hotels. While former studies have examined lodging firms' investments, financing, dividend, and cash policies, these studies did not investigate the differences between financially constrained and unconstrained lodging firms' respective policies. Therefore, in spite of the well-documented magnitude of the financial constraints problem in corporate finance literature, there is still critical need to examine whether there is a divergence between financially constrained and unconstrained lodging firms in terms of financing, investment, dividend, and cash holding policies. As stated in the study of Chirita et al., (2015), the implementation of development projects for recreational locations is also a way to attract tourists and new investments.

\section{METHODOLOGY}

\section{Measurement}

The sample of this study consists of the lodging companies that are publicly traded in the New York Stock Exchange, American Exchange, or NASDAQ during the period of 1995-2015. The sample was limited to firms with financial information available on the COMPUSTAT annual database. This database covers firms' annual financial reports, such as balance sheet, income statement, and statement of cash flow, which includes variables used in this study. The final sample consists of 242 firm-year observations.

Based on the finance and hospitality literature, the following variables are included in this study. Investment is measured by capital expenditures (item 128); cash is measured by cash and short-term investments (item 1); cash flow is measured by the income before extraordinary items (item 18) plus depreciation and amortization (item 14); size is measured by total assets (item 6); acquisition expenditures is the acquisitions (item 129); market value is defined as the number of common shares (item 54) times the fiscal year closing price for stock $i$ on year $t$ (item 199); leverage is measured as long term debt (item 9) plus debt in current liabilities (item 34) divided by total book assets; dividends is the common dividends (item 21); share repurchases is the purchases of common and preferred stock (item 115); earnings before interest, taxes, depreciation and amortization (EBITDA) is measured by operating income before depreciation (item 13); revenues is measured by sales (item 12); return on assets (ROA) is defined as the income before extraordinary items (item 18) divided by total assets (item 6); profit margin is measured by the income before extraordinary items (item 18) divided by revenues (item 12); and Tobin's $Q$ is defined as total assets plus firm's market value minus common equity (item 60), balance sheet deferred taxes (item 74) and leverage divided by total assets.

\section{Data collection}

Financial constraint indices are used as grouping variables to sort firms as constrained and unconstrained firm portfolios based on firms' degrees of financial constraints. Two different financial constraint indices are used to identify firms' financial constraint levels. Specifically, the Whited and $\mathrm{Wu}$ (2006) index and the Cleary index (Hennessy \& Whited, 2007) are utilized to sort firms as constrained and unconstrained. The WW and Cleary financial constraint indices are constructed following the methodologies used in Whited and Wu (2006) and Hennessy and Whited (2007), respectively as follows.

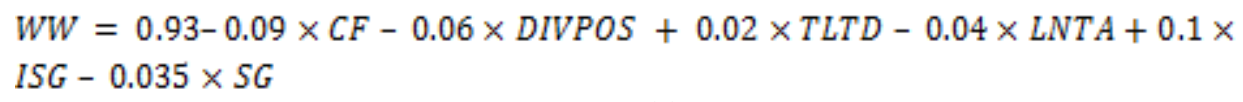




\section{Cleary $=-0.12 \times$ CURAT $-1.90 \times$ TLTD $+0.001 \times$ COVER $+1.46 \times$ IMARG $+2.03 \times$ SG - $0.05 \times$ SLACK}

(2)

where $C F$ is the cash flow; DIVPOS is an indicator that is equal to one if the firm pays dividends and zero otherwise; TLTD is the total long term debt (item 9); LNTA is the natural logarithm of total assets; $I S G$ is the sample firms' average sales growth; $S G$ is the firm's sales growth; CURAT is the current assets (item 4) divided by current liabilities (item 5); COVER is the interest coverage and measured as earning before interest and taxes (item 3 minus item 14) over interest expense (item 15) plus preferred dividend payments (item 19) divided by one minus tax rate, where tax rate equals to income taxes (item 16) divided by operating income before depreciation (item 13) minus depreciation and amortization (item 14) minus interest expense (item 15); IMARG is the net income (item 18) divided by sales (item 12); and $S L A C K$ is the financial slack measured as cash and short-term investments (item 1) plus 0.5 times inventory (item 3) plus 0.7 times accounts receivable (item 2) minus short term loans (item 196) divided by net fixed assets (item 8). Items are Compustat annual items and the constant term, 0.93, in the WW index is obtained from Franzoni (2009). A higher score of the index indicates greater financial constraints problems. Firms are categorized as constrained (above sample's median value) and unconstrained (below sample's median value) based on WW and Cleary financial constraint index values. Firms are also grouped as constrained and unconstrained based on their dividend paying policy, where firms are included in the constrained group if they do not pay any dividends and in the unconstrained group if they pay dividends.

\section{RESULTS}

Table 1 represents descriptive statistics (i.e., mean, median, and standard deviation) for the variables used in this study. Three alternative measures of financial constraints used in this study to test whether the differences between firms' performance measures remain persistent under different financial constraints specifications. Table 2 presents the correlation matrix for the financial constraint proxiesAccording to the correlation coefficients there is positive and significant relationships between three alternative financial constraint measures. Therefore, the financial constraint variables are reliable. Figure 1 illustrates the comparison of size, investment, EBITDA, dividends, revenues, and cash between financially constrained and unconstrained lodging firms using the WW financial constraint index throughout the study period.

Table 1. Summary Statistics

\begin{tabular}{|l|c|c|c|}
\hline \multicolumn{1}{|c|}{ Variables } & Mean & Median & Standard Deviation \\
\hline Cash & 153.77 & 38.59 & 254.99 \\
\hline Change in cash & 0.003 & 0.002 & 0.26 \\
\hline Cash Flow & 0.07 & 0.05 & 0.14 \\
\hline Investment (Capex) & 124.96 & 60.78 & 151.71 \\
\hline Acquisition Expenditures & 58.50 & 0 & 202.60 \\
\hline Total Assets & $2,773.55$ & 873.91 & $4,258.00$ \\
\hline Market Value & $2,540.53$ & 549.39 & $4,463.94$ \\
\hline Leverage & 0.43 & 0.39 & 0.26 \\
\hline Tobin's Q & 3.18 & 1.58 & 9.24 \\
\hline Dividends & 24.45 & 0 & 69.07 \\
\hline Share Repurchases & 101.87 & 0 & 332.96 \\
\hline EBITDA & 276.29 & 70.07 & 439.54 \\
\hline Revenues (Sales) & $1,693.88$ & 348.22 & $3,004.63$ \\
\hline Sales Growth & 0.19 & -0.01 & 1.46 \\
\hline Return on Assets & 0.01 & 0.02 & 0.05 \\
\hline Profit Margin & 0.01 & 0.04 & 0.13 \\
\hline
\end{tabular}


Table 2. Correlation Matrix of Financial Constraints Measures

\begin{tabular}{|c|c|c|c|}
\hline Variables & WW Index & Cleary Index & Dividend Payout Policy \\
\hline WW Index & 1 & & \\
\hline Cleary Index & $0.46^{\mathrm{a}}$ & 1 & \\
\hline Dividend Payout Policy & $0.5^{\mathrm{a}}$ & $0.44^{\mathrm{a}}$ & 1 \\
\hline \multicolumn{4}{|c|}{ a donates $1 \%$ statistical significance level } \\
\hline
\end{tabular}
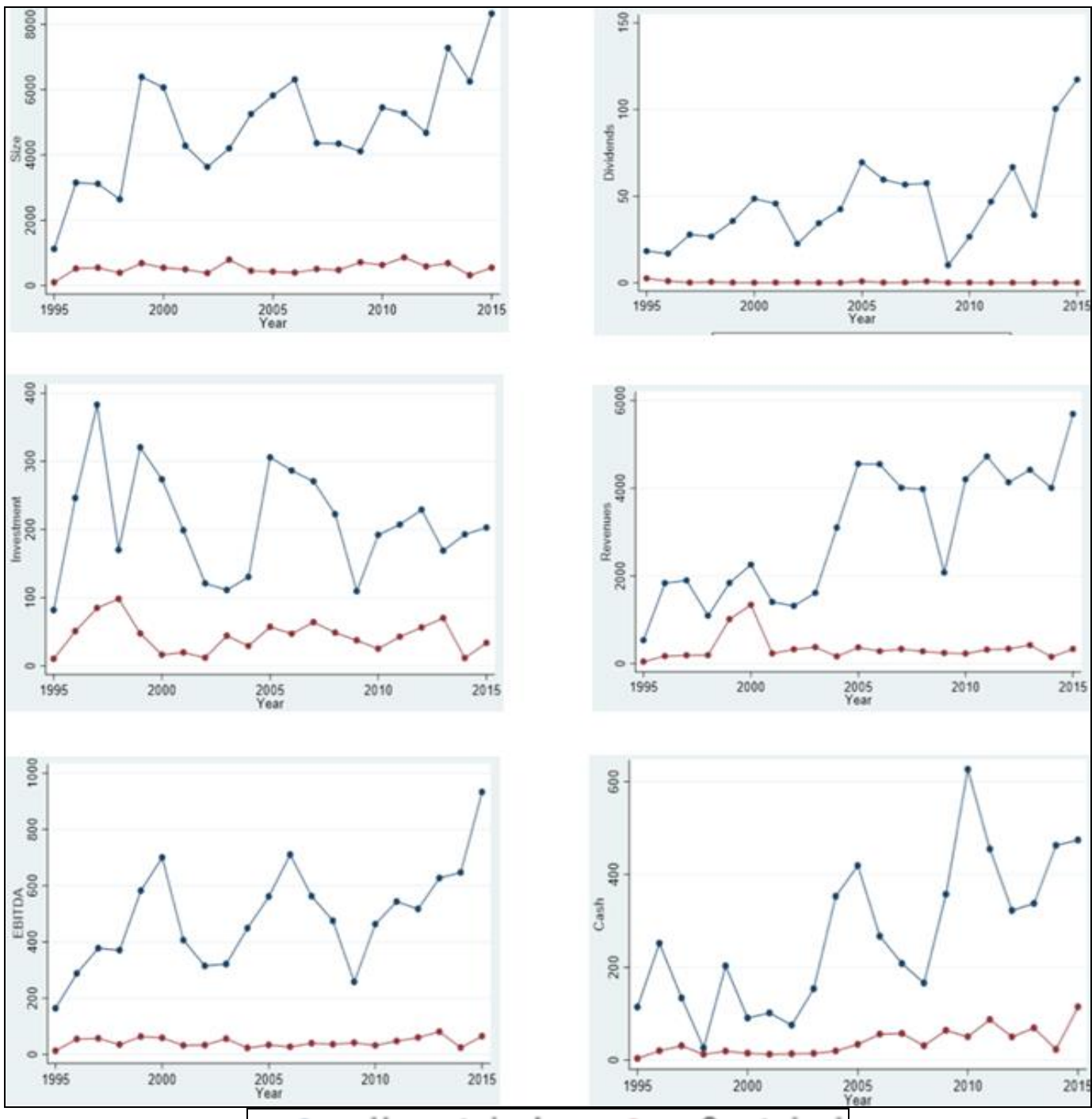

Figure 1. Comparison of Constrained and Unconstrationed Lodging Firms

While these values fluctuate over the years, financially constrained firms appear to be smaller in size, make less investment, have lower operating performance (EBITDA), pay lower dividends, generate lower revenues, and hold lower cash compared to financially unconstrained counterparts. These preliminary results seem to contradict some of the findings in mainstream corporate finance literature, where higher cash holdings and 
better performance were found for financially constrained firms. Nevertheless, further statistical analysis need to be conducted to provide evidence on the differences between financially constrained and unconstrained lodging firms' performances.

\section{Main Findings}

Independent sample t-test is conducted to test the mean differences between financially constrained and unconstrained lodging firms' firm performances. The selected firm measures are cash, change in cash, cash flow, investment (capex), acquisition expenditures, total assets, market value, leverage, Tobin's Q, dividends, share repurchases, EBITDA, revenues (sales), sales growth, return on assets, and profit margin using WW financial constraint index to categorize firms as financially constrained and unconstrained. Table 3 presents the results of these tests.

Table 3. The mean differences comparison between constrained and unconstrained lodging firms (WW Index)

\begin{tabular}{|l|c|c|c|c|}
\hline \multicolumn{1}{|c|}{ Variables } & Constrained & Unconstrained & t-value & Sig. \\
\hline Cash & 36.54 & 270.99 & 8.04 & $* * *$ \\
\hline Change in cash & 0.005 & 0.001 & -0.15 & N.S. \\
\hline Cash Flow & 0.08 & 0.06 & -1.65 & $*$ \\
\hline Investment (Capex) & 46.98 & 202.29 & 9.23 & $* * *$ \\
\hline Acquisition Expenditures & 16.63 & 102.27 & 3.23 & $* * *$ \\
\hline Total Assets & 540.14 & $5,006.97$ & 9.57 & $* * *$ \\
\hline Market Value & 332.67 & $4,748.4$ & 8.88 & $* * *$ \\
\hline Leverage & 0.52 & 0.34 & -6.01 & $* * *$ \\
\hline Tobin's Q & 2 & 4.35 & -1.98 & $*$ \\
\hline Dividends & 0.31 & 48.59 & 5.79 & $* * *$ \\
\hline Share Repurchases & 4.84 & 200.64 & 4.59 & $* * *$ \\
\hline EBITDA & 44.47 & 496.99 & 10.07 & $* * *$ \\
\hline Revenues (Sales) & 346.12 & $3,041.64$ & 7.8 & $* * *$ \\
\hline Sales Growth & 0.45 & -0.07 & -2.76 & $* *$ \\
\hline Return on Assets & -0.002 & 0.02 & 4.18 & $* * *$ \\
\hline Profit Margin & -0.01 & 0.04 & 3.38 & $* * *$ \\
\hline$* * * *^{* *}$, and * donate 1\%, 5\%, and 10\% statistical significance levels, respectively. N.S. donates not significant \\
\hline
\end{tabular}

The results show that there is a statically significant difference between financially constrained and unconstrained firms for all of the selected firm measures with the exception of change in cash variable. According to these results, financially constrained firms keep lower cash (36.54 vs. 270.99), make less investments both in acquisitions (16.63 vs. 102.27) and capital expenditures (46.98 vs. 202.29), are smaller in size in terms of total assets (540.14 vs. 5,006.97), have lower market value (332.67 vs. 4,748.4), pay much lower dividends (0.31 vs. 48.59) and make lower share repurchases (4.84 vs. 200.64), have lower operating performance (EBITDA) (44.47 vs. 496.99), and generate lower revenues (346.12 vs. 3,041.64). Furthermore, financially constrained firms have a negative return on assets and also negative profit margin, while financially unconstrained firms' return on assets and profit margins are positive. Nonetheless, financially constrained firms have higher cash flows compared to unconstrained firms (0.08 vs. 0.06) and much higher leverage (0.52 vs. 0.34). Tobin's Q, which is a proxy used to capture the growth opportunities of a company, is lower for financially constrained firms compared to unconstrained firms (2 vs. 4.35). A higher value of Tobin's Q indicates higher growth opportunities. It should be noted, however, that Tobin's $Q$ is not a reliable proxy as it may not very well capture the growth opportunities especially in small firms (Whited \& Wu, 2006). The difference in sales growth between financially constrained and unconstrained firms prove this point, as sales growth is 
higher in financially constrained firms than unconstrained firms (0.45 vs. -0.07). While these results provide significant evidence that the selected financial measures are significantly different for financially constrained and unconstrained lodging firms, we further analyze the mean differences using two alternative financial constraint proxies, namely Cleary index and dividend payout policy. Table 4 and Table 5 present these results.

Table 4. The mean differences between constrained and unconstrained lodging firms (Cleary Index)

\begin{tabular}{|l|c|c|c|c|}
\hline \multicolumn{1}{|c|}{ Variables } & Constrained & Unconstrained & t-value & Sig. \\
\hline Cash & 61.87 & 245.67 & -5.99 & $* * *$ \\
\hline Change in cash & 0.02 & -0.01 & 0.87 & N.S. \\
\hline Cash Flow & 0.05 & 0.09 & -2.43 & $* *$ \\
\hline Investment (Capex) & 66.25 & 183.19 & -6.47 & $* * *$ \\
\hline Acquisition Expenditures & 27.62 & 89.1 & -2.29 & $* *$ \\
\hline Total Assets & $1,040.54$ & $4,506.55$ & -6.92 & $* * *$ \\
\hline Market Value & 542.67 & $4,538.39$ & -7.77 & $* * *$ \\
\hline Leverage & 0.53 & 0.32 & 6.67 & $* * *$ \\
\hline Tobin's Q & 3.24 & 3.1 & 0.11 & N.S. \\
\hline Dividends & 6.57 & 42.33 & -4.16 & $* * *$ \\
\hline Share Repurchases & 6.09 & 199.37 & -4.53 & $* * *$ \\
\hline EBITDA & 85.76 & 455.69 & -7.71 & $* * *$ \\
\hline Revenues (Sales) & 461.09 & $2,926.67$ & -6.98 & $* * *$ \\
\hline Sales Growth & 0.03 & 0.34 & -1.65 & $*$ \\
\hline Return on Assets & -0.007 & 0.03 & -5.99 & $* * *$ \\
\hline Profit Margin & -0.02 & 0.05 & -5.47 & $* * *$ \\
\hline ******, and * donate 1\%, 5\%, and 10\% statistical significance levels, respectively. N.S. donates not significant \\
\hline
\end{tabular}

Table 5. The mean differences between constrained and unconstrained lodging firms (Dividend Payout)

\begin{tabular}{|l|c|c|c|c|}
\hline Variables & Constrained & Unconstrained & t-value & Sig. \\
\hline Cash & 111.04 & 227.23 & -3.49 & $* * *$ \\
\hline Change in cash & 0.001 & 0.006 & -0.12 & N.S. \\
\hline Cash Flow & 0.07 & 0.06 & 0.51 & N.S. \\
\hline Investment (Capex) & 82.42 & 197.61 & -6.1 & $* * *$ \\
\hline Acquisition Expenditures & 37.6 & 94.24 & -2.03 & $* *$ \\
\hline Total Assets & 1487.52 & 4984.35 & -6.7 & ${ }^{* * *}$ \\
\hline Market Value & 1117.86 & 4986.24 & -7.14 & $* * *$ \\
\hline Leverage & 0.46 & 0.36 & 3.12 & $* * *$ \\
\hline Tobin's Q & 3.79 & 2.11 & 1.37 & N.S. \\
\hline Dividends & 0 & 66.48 & -8.14 & $* * *$ \\
\hline Share Repurchases & 16.21 & 241.94 & -5.21 & $* * *$ \\
\hline EBITDA & 114.76 & 538.86 & -8.76 & $* * *$ \\
\hline Revenues (Sales) & 733.59 & 3344.72 & -7.16 & $* * *$ \\
\hline Sales Growth & 0.29 & 0.02 & 1.41 & N.S. \\
\hline Return on Assets & -0.003 & 0.03 & -4.55 & $* * *$ \\
\hline Profit Margin & -0.006 & 0.05 & -3.45 & $* * *$ \\
\hline$* * * * * *$ and * donate $\%, 5 \%$, and $10 \%$ statistical significance levels, respectively. N.S. donates not significant \\
\hline
\end{tabular}

The results from Table 4 and Table 5 confirm the mean difference test results using WW index with few exceptions. For example, the difference between Tobin's Q means for financially constrained and unconstrained firms is not statistically significant using Cleary index and dividend payout policy financial constraint measures, which brings into question the reliability of the Tobin's Q in measuring firms' growth opportunities. Also, the differences between cash flow and sales growth are statistically insignificant based on dividend payout policy measure of financial constraints. Despite the few inconsistencies 
between financial constraint indices of WW index, Cleary index, and dividend payout policy, the results provide substantive evidence that financially constrained firms keep lower cash, make less investments, are smaller in size and value, pay lower dividends, have lower performance, and have a negative return on assets and negative profit margin. However, financially constrained firms have higher leverage compared to unconstrained firms. (We further analyzed the median differences between financially constrained and unconstrained firms for the selected financial variables. The results were consistent with the findings using mean difference test and are available from the authors upon request.)

\section{CONCLUSION AND IMPLICATIONS}

CEOs of financially constrained lodging firms might bypass a positive NPV investment, if internal funds are not sufficient. Financial constraint problems may cause lodging firms to operate in a suboptimal investment level, which in turn can affect firm cash and dividend policies. This study compared divergence between financially constrained and unconstrained lodging firms' performance measures, such as EBITDA, sales, sales growth, return on assets, and profit margin to analyze the nature and implications of financial constraint problems in the U.S. lodging sector. The results show that financially constrained firms have lower cash holdings but higher cash flows, suggesting that these firms have higher investment and operating activities. Although financially constrained firms make fewer investments and are smaller in size and value, they have better growth prospects. The results also showed that financially constrained firms pay lower dividends, which is in line with theoretical expectations. Obviously, larger firms are more likely to pay higher dividends because they are in a maturity phase, where further growth may be a trickle. While financially constrained firms generate lower revenues, which seems to contradict the findings in mainstream corporate finance literature, these could be mainly due to the fact that financially constrained firms are smaller in size and value. Hence, they have limited sources of revenues, as these firms are likely to be young and small compared to unconstrained firms. Although financially constrained firms have negative return on assets and profit margin, they are likely to be profitable as they mature because these firms have growth opportunities. While the results from this study showed that there are significant differences between financially constrained and unconstrained firms financial measures, why these firms are constrained is not clear. Financially constrained hotel firms have higher leverage as opposed to the general notion that financially constrained firms cannot raise external funds to make investments. This contradictory finding suggests that financial constraints in the lodging industry might not be due to capital market imperfection but probably these firms are financially constrained because they are overly-levered. High leverage increases risk of bankruptcy, especially during economic downturns, while firms with lower leverage are more likely to survive during recessions. While financially constrained firms are less likely to make investments in research and development, hotel firms do not seem to make investments in research and development regardless of the degree of financial constraints. Overall, the results from this exploratory study suggest that lodging firms' characteristics are different from firms in other industries.

\section{Industry Implications}

Managerial and practical implications of this study are noteworthy. Financially constrained hotel firms should retain more of their cash instead of distributing them to shareholders to eliminate underinvestment problems and potentially bankruptcy. The retrained earnings allow managers to allocate internal resources efficiently and ultimately to increase investment to an optimal investment level, where the firm value is maximized. Financially constrained firms may be able to reduce the wedge between external and internal funds in acquisitions because asymmetric information between acquiring firms and the target company could be fewer in relation to the capital markets. Furthermore, 
financially constrained firms with growth prospects should consider expanding through franchising when they have insufficient cash to undertake positive NPV projects. Expansion through franchising eliminates the need for costly external finances because franchisor does not require substantial capital investment. Financially constrained hotel firms might be profitable investment opportunities for stock market investor because these firms indicate growth prospects. However, stockholders should closely examine these firms' leverage, as excess leverage may lead to bankruptcy.

\section{Limitations and Recommendations for Future Research}

Despite its contribution to the hospitality and corporate finance literature, this study has limitations. The existing financial constraint measures are developed based on firms' including all industries. Although these financial constraint indices can be used to measure lodging firms' degree of financial constraints, they may not capture idiosyncratic characteristics of the lodging industry. Therefore, future studies may develop financial constraint proxies to capture the unique characteristics of the lodging industry. These future studies may cover different geographical regions as well. The lack of investments in research and developments requires further investigation especially for unconstrained hotel firms. Also, the value of investment, cash holdings, and investment-cash flow sensitivity should be further examined to determine the extent to which financial constraints affect firms' value of investment, cash holdings, and dependence on cash flow for investment.

\section{REFERENCES}

Canina, L., Advani, R., \& Palimeri A.G.I. (2001). Dividend policy in the lodging industry. Journal of Hospitality \& Tourism Research, 25, p. 68-89.

Chirita, V., Lupchian, M.M., \& Matei, D. (2015). The Vatra Dornei tourism development through local entrepreneurship (Romania). Geojournal of Tourism and Geosites, 2(16), p.206-216.

Dalbor, M., Lee, S., \& Upneja, A. (2007). An investigation of long-term debt and firm value in the lodging industry. Advances in Hospitality and Leisure, 3, p. 195-204.

Denis, D.J, \& Sibilkov, V. (2009). Financial constraints, investment, and the value of cash holdings. Review of Financial Studies, 23., p. 247-269.

Fazzari, S.M., Hubbar, R.G., \& Petersen, B.C. (1988). Financing constriants and corporate investment. Brookings Papers on Economic Activity, p. 141-206.

Franzoni, F. (2009). Underinvestment vs. overinvestment: Evidence from price reactions to pension contributions. Journal of Financial Economics, 92, p. 491-518.

Hennessy, C.A., \& Whited, T.M. (2007)..How Costly Is External Financing? Evidence from a Structural Estimation, The Journal of Finance, 62, p. 1705-1745.

Kaplan, S.N, \& Zingales, L. (1997). Do investment-cash flow sensitivities provide useful measure of financing constraints? The Quarterly, Journal of Economics, 112, p. 169-215.

Karmin, C. (2016). Hotel Investors Check Out Early. Wall Street Journal, http://www.wsj.com/articles/hotelinvestors-check-out-early-1455648219.

Khatami, S.H, Marchica, M.T., \& Mura, R. (2014). Corporate acquisitions and financial constraints. Working Paper, Available at SSRN 2246644.

Kim, H., \& Gu, Z. (2009). Financial features of dividend-paying firms in the hospitality industry: A logistic regression analysis. International Journal of Hospitality Management, 28, p. 359-366.

Kim, J., \& Jang, S. (2012). Do hotel REIT companies face investment constraints? A comparison with Ccorporation hotel companies. International Journal of Hospitality Management, 31: 573-578.

Modigliani, F., \& Miller, M.H. (1958). The Cost of Capital, Corporation Finance and the Theory of Investment. The American Economic Review, 48: 261-297.

Myers, S.C., \& Majluf, N.S. (1984). Coporate financing and investment decision when firms have information that investors do not have, Journal of Financial Economics, 13: 187-221.

Sheel, A. (1994). Determinants of capital ctructure choice and empirics on leverage behavior: A comparative analysis of hotel and manufacturing firms, Journal of Hospitality \& Tourism Research, 17: 3-16.

Whited, T.M., \& Wu, G. (2006). Financial constraints risk. Review of Financial Studies, 19: 531-559.

Submitted:

03.05.2018
Revised:

08.10.2018
Accepted and published online 10.10.2018 